\title{
OBCHODY DNIA SANDŻAKU A KONSTRUOWANIE WSPÓŁCZESNEGO BOSZNIACKIEGO DYSKURSU PAMIĘCI ${ }^{1}$
}

\author{
NADIA CZACHOWSKA-ALEKSIĆ
}

\begin{abstract}
A case study of the Sandžak day celebration and constructions of the modern Bosniak memory discourse. The paper is a critical analysis of the Sandžak Day celebrations in Serbia. The ritual activities taking place during grand ceremonies as well as the historical narrative presented by the Bosnian elite are subject to reflection in this doubly peripheral area. Using such research categories as ritual, invented tradition, site of memory and historical myth, the elements that constitute the Sandžak-Bosnian identity have been characterized. Their analysis made it possible to define the mechanisms of the construction of the contemporary Bosnian discourse of memory in Sandžak and to identify the visible tendencies of this narrative.
\end{abstract}

STReSzCZENIE. Artykuł jest krytyczną analizą przebiegu obchodów Dnia Sandżaku w Serbii. Poddane namysłowi zostały czynności rytualne mające miejsce podczas uroczystych ceremonii, jak i narracja historyczna, którą prezentuje boszniacka elita. Za pomocą takich kategorii badawczych jak pamięć kulturowa, tradycja wynaleziona, rytuał oraz mit historiograficzny, scharakteryzowane zostały elementy, które są częścią składową sandżacko-boszniackiej tożsamości. Ich analiza pozwoliła na zdefiniowanie mechanizmów konstrukcji współczesnego boszniackiego dyskursu pamięci na terenie Sandżaku oraz umożliwiła określenie widocznych tendencji tej narracji.

Author: Nadia Czachowska-Aleksić, Uniwersytet im. Adama Mickiewicza w Poznaniu, Instytut Filologii Słowiańskiej, nadia.czachowska@gmail.com, ORCID iD: https://orcid.org/0000-0002-2122-8325

Keywords: Sandjak, Bosniaks, double periphery, memory, narratives, discourse, ritual, past

Słowa kluczowe: Sandżak, Boszniacy, podwójna peryferia, pamięć, narracje, dyskurs, rytuał, przeszłość

Balcanica Posnaniensia. Acta et studia, XXVIII/2, Poznań 2021, Wydawnictwo Wydziału Historii UAM, pp. 161-178, ISBN 978-83-66355-84-2, ISSN 0239-4278. Polish text with summaries in English and Polish

doi.org/10.14746/bp.2021.28.25

1 Tekst powstał w ramach projektu Ideology, identity and violence center and periphery in the contemporary texts of Serbian culture, który został sfinansowany w ramach Programu im. Iwanowskiej ( $N a$ rodowa Agencja Wymiany Akademickiej, nr PPN/IWA/2019/1/00176/DEC/1). 


\section{WSTĘP}

Przedmiotem mojego zainteresowania jest sytuacja boszniackiej mniejszości narodowej, zamieszkującej południowo-zachodnie rejony Serbii, czyli tak zwany Sandżak. Jest to społeczność, która w sensie geograficznym i politycznym ma charakter peryferyjny względem Belgradu - centralnego ośrodka w państwie, w którym znajdują się siedziby władz i najważniejszych instytucji państwowych. Ze względu na przygraniczne usytuowanie, swoistą charakterystykę etno-religijną i przeszłość, Sandżak bywa określany przez badaczy jako „podwójna peryferia” w stosunku do Belgradu i Sarajewa. O ile w pierwszym znaczeniu peryferyjność tego regionu jest definiowana w kontekście jego podległości państwowej (Belgrad), tak z drugiej strony odnosi się ona do relacji natury religijno-narodowej, jako że duża część tamtejszej ludności wyznaje islam i jednocześnie identyfikuje się z boszniacką tożsamością narodową (Sarajewo). Zjawisko podwójnej peryferyjności opisywanego regionu stało się szczególnie widoczne w następstwie rozpadu Socjalistycznej Federacyjnej Republiki Jugosławii (SFRJ), na początku lat dziewięćdziesiątych XX wieku. W czasach jugosłowiańskich Socjalistyczna Republika Bośnia i Hercegowina, ze względu na fakt, że względną większość jej ludności stanowili Muzułmanie (uznawani za jeden z narodów konstytucyjnych socjalistycznej Jugosławii) była ważnym punktem odniesienia dla wyznawców islamu z Sandżaku, znajdującego się na terenie socjalistycznej Serbii i Czarnogóry. Wraz z ukonstytuowaniem się niezależnej BiH, wśród słowiańskich społeczności muzułmańskich żyjących na Bałkanach, zwłaszcza w państwach sąsiednich, zaczęto ją postrzegać jako źródło inspiracji w zakresie działań tożsamościowych. W przypadku liderów muzułmańskiej społeczności Sandżaku, Sarajewo jest uznawane za ośrodek ,patronujący” aktywności w kierunku rozwijania i ugruntowania boszniackiej tożsamości narodowej w regionie. Nie przekłada się to na bezpośrednią ingerencję władz BiH w sprawy Sandżaku, który jest integralną częścią Serbii. W tym przypadku chodzi raczej o „twórcze impulsy”, płynące z zewnątrz, pomagające w konkretyzowaniu kulturowych i organizacyjnych ram mniejszości boszniackiej, żyjącej w Republice Serbii.

Do końca lat osiemdziesiątych XX wieku, gdy istniała SFRJ, Komunistyczna Partia Jugosławii była jedynym „,entrum produkcji wiedzy”, przez co w oficjalnym dyskursie dominowała jedna wersja historii narodów jugosłowiańskich. Wraz z rozpadem federacji, część jej dotychczasowych peryferii przekształciła się w ośrodki o charakterze stołecznym. Zdaniem historyka Srđana Miloševicia, zakłócony zostal system wartości oraz postrzeganie historii, a kryterium etniczne stało się ważniejsze niż etyczne $e^{2}$. Zmiana podejścia do historii narodowej i narastająca rywalizacja pomiędzy poszczególnymi etno-narracjami na temat przeszłości, wydatnie wpłynęły na ukształtowanie się nowej atmosfery w kontaktach pomiędzy poszczególnymi wspól-

2 S. Milošević, Ulica Milana Nedića u Aranđelovcu, „N1 info” 2017, http://rs.n1info.com/Vesti/ a346534/Ulica-Milana-Nedica-u-Arandjelovcu.html [dostęp: 03.01.2021]. 
notami etno-narodowymi, zdominowanej przez narastającą niechęć a nawet wrogość. Dostrzegalne to jest także w przypadku Sandżaku, gdzie od kilku dekad konkurują ze sobą odrębne, rozbieżne interpretacje historii, boszniacka oraz serbska. Do kwestii spornych należy więc nie tylko używanie tradycyjnej nazwy regionu (Sandżak), ale i określanie jego muzułmańskich mieszkańców za pomocą terminów Sandžaklije (odnoszącego się do podziałów regionalnych) bądź Bošnjaci (akcentującego łączność narodową sandżackich muzułmanów z Boszniakami z BiH).

Celem artykułu jest przegląd działań, zmierzających do konstruowania tzw. współczesnego sandżackiego dyskursu pamięci, z naciskiem na przedstawienie najważniejszych stanowisk, prezentowanych przez poszczególnych działaczy społeczno-politycznych oraz kulturalnych, którzy identyfikują się z tamtejszą ludnością muzułmańską. Za podstawę analizy posłuży ogólna charakterystyka święta regionalnego o nazwie Dzień Sandżaku, które od 2005 roku jest corocznie organizowane w serbskiej części Sandżaku w dniu 20 listopada. Oficjalne obchody odbywają na terytorium Republiki Serbii i właśnie na tej części historycznego Sandżaku skupię swoją uwagę 3 . Dzień Sandżaku został ustanowiony na podstawie decyzji podjętej przez działającą w Belgradzie Narodową Radę do Spraw Mniejszości Narodowych, powołaną do życia w związku z ustawą o ochronie mniejszości narodowych z 2004 roku. Na terenie gmin Nowy Pazar, Sjenica i Tutin, które są w większości zamieszkane przez ludność identyfikującą się z etnosem boszniackim, jest to czas wolny od pracy. Data święta odnosi się do rocznicy stworzenia, 20 listopada 1943 roku, Ludowej Antyfaszystowskiej Rady Wyzwolenia Narodowego Sandżaku (Zemaljsko Antifašističko Vijeće Narodnog Oslobođenja Sandžaka, ZAVNOS), która była politycznym organem komunistycznego ruchu oporu (1943-1945).

Pod względem programowym i organizacyjnym coroczne Dni Sandżaku są adresowane do lokalnej ludności muzułmańskiej. Mają one formułę dwudzielną, jako że odbywają się w ramach dwóch rywalizujących ze sobą społeczności wyznaniowych. Mowa o Islamskiej Wspólnocie Bośni i Hercegowiny (Islamska Zajednica Bosne i Hercegovine, IZ BiH) oraz Islamskiej Wspólnocie Serbii (Islamska Zajednica Srbije, IZ Srbije), która powstała w 2007 roku w opozycji wobec IZ BiH i ma swoją siedzibę w Belgradzie. Z kolei IZ BiH jest uznawana za najwyższy organ przedstawicielski muzułmanów w regionie, zwłaszcza w tzw. państwach postjugosłowiańskich i diasporze boszniackiej. W rezultacie, jeden z trzech oddziałów IZ Srbije, który znajduje się w Nowym Pazarze (mešihat Sandžaka), rywalizuje w Sandżaku o wpływy z miejscowym przedstawicielstwem IZ BiH. Obchody dnia Sandżaku odbywają

3 Warto zauważyć, że poszczególne społeczności boszniackie, identyfikujące się z Sandżakiem, obchodzą Dzień Sandżaku także w Czarnogórze (Bijelo Polje, Rožaje), Sarajewie i w ramach diaspory (Wiedeń, Frankfurt, Monachium, Zurych). Świętowanie trwa nawet kilka dni. Szczególnie ważne są w tym przypadku obchody w Sarajewie, gdzie podkreśla się konieczność umacniania relacji z Boszniakami zza wschodniej granicy i kładzie nacisk na transgraniczny charakter Sandżaku; Dan Sandžaka 2010, „Mešihat”, https://mesihat.org/2010/11/10/dan-sandaka-2010/ [dostęp: 03.01.2021]. 
się w tym samym dniu, ale niezależnie w dwóch lokalizacjach i skupiają muzułmanów z wrogo nastawionych wobec siebie środowisk ${ }^{4}$.

W zbiorowej pamięci Serbów obszar regionu historycznego o nazwie Sandżak znajduje się w ścisłej czołówce ,świętych” miejsc narodowych. Na tych terenach w X wieku istniały pierwsze państwa serbskie. Tam znajdowała się też pierwsza serbska stolica średniowiecznego państwa Raszka i właśnie za pomocą tego terminu Sandżak nadal jest określany przez wielu Serbów. W czasach osmańskich (XVXIX wiek) wprowadzono tam podział administracyjny, oparty na sandżakach. Nazwa omawianego regionu, będąca w powszechnym użyciu wśród zamieszkujących go muzułmanów (Boszniaków), wywodzi się od sandżaku nowopazarskiego (z głównym ośrodkiem Nowy Pazar). Nie występuje ona w oficjalnej nomenklaturze geograficznej współczesnej Republiki Serbii oraz Republiki Czarnogóry. Z perspektywy mieszkańców Sandżaku, do regionu zaliczają się jednak zarówno gminy znajdujące się w Serbii (Nowy Pazar, Tutin, Sjenica, Prijepolje, Nova Varoš, Priboj), jak i Czarnogórze (Pljevlja, Bijelo Polje, Berane, Plav, Rožaje) ${ }^{5}$.

Nazwa Sandżak nie jest oficjalnie uznawana przez państwo serbskie i nie uwzględnia się jej w nazewnictwie administracyjnym ${ }^{6}$. Nie zmienia to faktu, że termin ten znajduje się w powszechnym użyciu i to nie tylko wśród miejscowych Boszniaków. W Serbii, gdzie dominuje wyznanie prawosławne, ludność ta stanowi drugą co do wielkości mniejszość etniczną i religijną i koncentruje się właśnie na terenie Sandżaku. Według spisu ludności z 2011 roku odsetek osób utożsamiających się z narodowością boszniacką sięgał na tym terytorium blisko 60\%. W trzech spośród sześciu gmin, zaliczanych do regionu, Boszniacy stanowili przewagę: Tutin (90\%), Nowy Pazar $(77 \%)$, Sjenica $(73 \%)^{7}$. Tamtejsze instytucje religijne i działające lokalnie partie polityczne używają w swoim nazewnictwie określenia „Sandżak”, np. Sandżacka Partia Demokratyczna (Sandžačka demokratska partija; SDP), Partia Akcji Demokratycznej Sandżaku (Stranka demokratske akcije Sandžaka, SDA Sandžaka), gmina wyznaniowa Sandżaku (muftijstvo sandžačko). Są wśrod nich media: prywatna telewizja i ga-

4 Por. D. Mikucka-Wójtowicz, Sytuacja mniejszości boszniackiej w Sandżaku — wyzwania i proble$m y$, ,Sprawy Narodowościowe” 2013, nr 42, s. 143-167.

5 Boszniacy pod pojęciem Sandżak rozumieją tereny leżące w dzisiejszej Serbii i Czarnogórze. W moim przekonaniu granica państwowa serbsko-czarnogórska, która od kilkunastu lat przebiega przez ten region historyczny, przyczynia się do ugruntowania różnic, dotyczących np. wpływu odmiennych centralnych ośrodków władzy na poszczególne części Sandżaku (Belgrad i Podgorica).

6 Według badań przeprowadzonych przez Krzysztofa Marcina Zalewskiego, percepcja terminu „Sandżak” ewoluowała wraz z rozpadem socjalistycznej Jugosławii od regionu historyczno-geograficznego w kierunku pojęcia o wymiarze etno-religijnym: na przełomie lat osiemdziesiatych i dziewięćdziesiątych (...) Sandżak jako region doświadczyt kolejnej geopolitycznej i semantycznej rewolucji. (...) Semantyczna rewolucja polegała na tym, że sandżackość zaczęła być identyfikowana wyłacznie z muzutmańskim/boszniackim programem narodowym; por: K. M. Zalewski, Naród, religia, rasa. Muzułmańskie ideologie i ruchy narodowe pogranicza w Poludniowo-Wschodniej Europie. Przykład Sandżaka nowopazarskiego wXX wieku, Warszawa 2010, s. 81.

7 Republički zavod za statistiku, http://popis2011.stat.rs/ [dostęp: 04.01.2021]. 
zeta sandżacka („Sandžačka televizija”, „Sandžačke novine”) i organizacje pozarządowe (Sandžački odbor za zaštitu ljudskih prava i sloboda). Ze względu na swoją długą tradycję i popularność na poziomie regionalnym, określenie Sandżak pojawia się także w tzw. centralnym dyskursie serbskim. Jest to widoczne głównie w mediach opozycyjnych względem władz centralnych. I tak, w elektronicznym wydaniu niezależnego tygodnika „Danas” odnaleźć można „,tag” sandžak ${ }^{8}$, dzięki któremu czytelnik korzysta $\mathrm{z}$ dostępnych na stronie gazety tekstów prasowych o regionie. W innych mediach o zasięgu ogólnopaństwowym, np. w czasopiśmie „Vreme” lub w materiałach prezentowanych na antenie prywatnej telewizji „N1”, określenie to jest natomiast przytaczane głównie w kontekście wypowiedzi polityków będących przedstawicielami mniejszości boszniackiej z Serbii.

Istotnym jest także, aby zaznaczyć w tym miejscu moje konstruktywistyczne stanowisko dotyczące kwestii omawianego terytorium. Spór i dyskusje dotyczące istnienia bądź nieistnienia Sandżaku jako odrębnego regionu uważam za nieistotne dla moich badań i dlatego nie poświęcam im uwagi w tym artykule. Liczy się dla mnie natomiast samo jego pojawianie się i znaczenie, jakie jest mu przypisywane w dyskursach społecznych.

\section{KATEGORIE BADAWCZE}

W analizie mechanizmów rządzących procesami kulturowymi w Sandżaku ważne jest uwzględnienie czterech ogólniejszych kategorii badawczych: wspomnianej już podwójnej peryferii, a także rytuału, miejsc pamięci oraz mitu. Podwójna peryferyjność opisywanego regionu wynika z faktu, że z jednej strony jest on zależny od centrum polityczno-administracyjnego, jakim jest Belgrad, z drugiej znajduje się w strefie oddziaływania tzw. „centrum duchowego”, utożsamianego z Sarajewem 9 . Dodajmy, że w literaturze naukowej określenie ,podwójna peryferia” jest najczęściej używane w odniesieniu do relacji ekonomicznych i systemowych, przeważnie dotyczących Europy środkowo-wschodniej ${ }^{10}$. Termin ten pojawił się również w literaturoznawstwie. Analizując Kronikę Trawnicka (Travnička hronika), jedno z dzieł najwybitniejszego pisarza czasów jugosłowiańskich Ivo Andricia, bośniacki teoretyk literacki z Uniwersytetu w Sarajewie Enver Kazaz wymienił dwa źródła ideologii

8 Sandžak (tag), Danas, https://www.danas.rs/tag/sandzak/ [dostęp: 03.01.2021].

9 Dogłębny przegląd historii badań nad granicami zaprezentowali: H. Donnan, T. M. Wilson, Granice tożsamości, narodu, państwa, thum. M. Głowacka-Grajper, Kraków 2007. Studia o metodologicznych ujęciach pogranicza: K. Dolińska, Teoretyczne i metodologiczne aspekty badania sqsiedztwa na pograniczu, [w:] Sasiedztwa III RP - Czechy. Zagadnienia społeczne, red. M. Dębicki, J. Makaro, Wrocław 2013; N. Niedźwiecka-Iwańczak, Granice a pogranicze i transnarodowość, [w:] Transgraniczność w perspektywie socjologicznej. Europa - podzielona wspólnota?, red. M. Zielińska, D. Szaban, B. Trzop, Zielona Góra 2018; M. Hughson, Poluperiferija i rod. Pobuna konteksta, Beograd 2015.

10 Por. S. Magala, Double peripherisation, „Review” 1985, t. 9, nr 1, 1985, s. 139-151. 
kulturowych, leżących u podstaw tzw. kultury bałkańskiej: eurocentryczne i orientalne. Jak stwierdził, Batkany i BiH, jako ich integralna czesść w Kronice Trawnickiej, jawia się jako ideologicznie skonstruowane podwójne peryferie, a nawet podwójna wewnętrzna odmienność (... $)^{11}$.

Rytuał, do którego odwołuję się w charakterystyce obchodów Dnia Sandżaku, jest interpretowany w nauce jako cześć tradycji i pamięci kulturowej oraz swoisty nośnik pamięci zbiorowej. Jak stwierdził niemiecki historyk Jan Assmann, rytuał polega na (re)konstruowaniu sensu porzadku społecznego poprzez wspólnotowe działania symboliczne $^{12}$. W przypadku Sandżaku należy wziąć pod uwagę rolę rytuału w kreowaniu i umacnianiu tradycji o dość świeżej metryce, którą w badaniach antropologicznych określa się jako tzw. tradycję wynalezioną. W rozumieniu brytyjskiego historyka Erica Hobsbawma, taka tradycja ma charakter zideologizowany, rytualny i symboliczny. Służy podtrzymywaniu więzi wewnątrz danej społeczności i zaznaczeniu jej związków z przeszłością ${ }^{13}$. Jej rytualizacja dokonuje się poprzez powtarzanie pewnych treści w przestrzeni publicznej, chociażby poprzez stosowanie tzw. rytualu politycznego. Zdaniem politolożki Małgorzaty Kołodziejczak takie rytuały należy analizować z dwóch perspektyw, zewnętrznej - tego, co mi się przydarza (Erfahrungen) $i$ wewnętrznej - tego, co przeżywam (Erlebnisse) ${ }^{14}$. Pierwsza perspektywa odnosi rytuał do relacji z państwem i jego instytucjami, druga jest nastawiona na wrażenia i emocje wynikające z postrzegania poszczególnych wydarzeń przez ich uczestników lub bezpośrednich obserwatorów. W kontekście rytuału M. Kołodziejczak przywołuje także kategorię przestrzeni o wymiarze sacrum, w której ma on szanse zaistnieć i oddziaływać z pełną siłą. W tym ujęciu, sfera sacrum posiada wyższa godność $i$ większa moc niż rzeczy świeckie ${ }^{15}$ (sfera profanum). Uroczystości związane z Dniem Sandżaku warto postrzegać właśnie przez pryzmat ich rytualizacji. Zgodnie z opisem francuskiego filozofa Emila Durkheima, celem tego typu świąt jest wzniecenie silnych emocji, zbliżenie ludzi i poruszenie mas ${ }^{16}$. W tym kontekście rytuał, poprzez odpowiednio określony przekaz symboliczny, tworzy „dynamikę działań” i nadaje im wymiar transcendentalny (,konstruktywny wymiar rytuału”). Ważnym aspektem oficjalnej celebracji jest przenikanie rytuału do praktyki życia codziennego, tak aby celebrowane treści nabrały uroczystego, ponadczasowego znaczenia dla społeczności.

11 E. Kazaz, Treći svijet i njegova mudrost isključenosti. Slika imperijalne ideologije i prosvjetiteljske utopije u Andrićevoj „,Travničkoj hronici”, [w:] Слика другог у балканским и средњоевропским књижевностима, red. Миодраг Матицки, Београд 2006.

12 J. Assmann, Collective Memory and Cultural Identity, „New German Critique” 1995, nr 65, S. 132 .

13 E. Hobsbawm, T. Ranger, Tradycja wynaleziona, tłum. M. Godyń, F. Godyń, Kraków 2008, s. 10, 13; J. Assmann, op. cit., s. 132.

14 M. Kołodziejczak, Rocznicowe rytuały smoleńskie w perspektywie neodurkheimizmu, „Przegląd Politologiczny" 2015, nr 2, s. 148.

15 E. Durkheim, Elementarne formy życia religijnego, Warszawa 1990, s. 32.

16 Ibidem, s. 367. 
Kategoria miejsc pamięci nie musi oznaczać konkretnego miejsca, ulokowanego w przestrzeni fizycznej. Wedle francuskiego socjologa Pierre'a Nory termin ten odnosi się raczej do „wszelkiego rodzaju praktyk”, nakierowanych na podtrzymanie pamięci o przeszłości ${ }^{17}$. Ważne jest, aby poszczególne elementy pamięci zbiorowej mogły zostać przekazane odbiorcy poprzez rytuały bądź symbole, identyfikowane z daną społecznością. $\mathrm{Z}$ tego punktu widzenia eksponowanie np. flag w przestrzeni publicznej jest uznawane jako ważna część procesu wizualizacji pamięci, czyli zjawiska, którego istota jest dominacja wydarzeń wizualnych w procesie transmisji i percepcji przeszłośc $i^{18}$. Z kolei mit jako kategoria badawcza, jest przeze mnie rozumiany jako „sformułowanie”, któremu bez weryfikacji nadano status prawd faktograficznych (Jerzy Topolski). W tym sensie można mówić o czterech typach mitów. Są to opowieści o początkach świata, projekcje dotyczące przyszłości, mity historiograficzne (narracyjne) i mity fundamentalne. Zdaniem poznańskiego historyka J. Topolskiego, dla zrozumienia procesu produkcji narracji historycznej kluczowe jest rozpoznanie przede wszystkim mitów historiograficznych i fundamentalnych ${ }^{19}$ :

Mity historiograficzne powstają poprzez dwa podstawowe procesy. Pierwszym z nich jest dostawanie się do narracji historycznej informacji nie mających oparcia w wiarygodnych źródłach (a także nieuprawniona amplifikacja informacji z pochodzących źródeł), zaś drugim stała - jak się wydaje - właściwość myślenia ludzkiego polegająca na niechęci poddawania własnych konstatacji testowi falsyfikacji, co prowadzi do „unieruchamiania” mniejszych czy większych partii narracyjnych, czyli ich dogmatyzowania (mitologizowania).

Opisane powyżej podejścia wskazują na procesy konstruowania mitów, np. poprzez wprowadzanie poszczególnych narracji historycznych do świadomości zbiorowej mieszkańców. W przypadku Sandżaku działania te są podejmowane właśnie przy okazji corocznego święta regionalnego. Na tym przykładzie można dostrzec i zbadać tendencje rządzące kształtowaniem się i formalizowaniem współczesnego boszniackiego dyskursu pamięci.

17 P. Nora, Between memory and history. Les lieux de mémoire, „,Representation” 1989, nr 26, za: A. Szpociński, Miejsca pamięci (lieux de mémoire), „Teksty Drugie” 2008, nr 4, s. 13.

18 A. Szpociński, Wizualizacja pamięci społecznej, [w:] Pamięć zbiorowa jako czynnik integracji iźródto konfliktów, red. Andrzej Szpociński, Warszawa 2009, s. 228.

19 J. Topolski, Jak się pisze i rozumie historię. Tajemnice narracji historycznej, Warszawa 1996, s. 204-206. 


\section{ŚWIĘTO SANDŻAKU A BOSZNIACKI DYSKURS PAMIĘCI ${ }^{20}$}

Dyskurs pamięci, prezentowany przez lokalne elity podczas obchodów Dnia Sandżaku jest złożony, obfituje w przykłady (re)interpretacji, przeformatowania przeszłości, a także afirmacji jej spornych elementów. I tak, w ramach tych uroczystości od 2006 roku odbywają się Sandżackie Spotkania Literackie (Sandžački književni susre$t i$, SAKS), podczas których jest wręczana nagroda o nazwie Pióro Ćamila Sijaricia (Pero Ćamila Sijarića $)^{21}$. Jest ona przyznawana literatom pochodzącym z Sandżaku, tworzącym w języku boszniackim. Organizatorem imprezy jest Boszniacka Rada Narodowa (Bošnjačko Nacionalno Vijeće, BNV), powiązana z partią SDA Sandżaku, która z kolei ściśle współpracuje z działającą w BiH muzułmańską Partią Akcji Demokratycznej (Stranka Demokratske Akcije, SDA). Co roku organizowana jest także uroczysta akademia, podczas której są recytowane fragmenty „sandżacko-boszniackiej poezji”, zależnie od programu odbywają promocje książek i wystawy sztuki, przedstawienia w wykonaniu dzieci i młodzieży. Intencją BNV jest popularyzacja twórczości literackiej w języku bośniackim, dotyczącej Sandżaku ${ }^{22}$. W dalszej perspektywie zabiegi te są obliczone na stworzenie czegoś w rodzaju „boszniackiego kanonu literackiego", z którym utożsamiałaby się ludność muzułmańska zamieszkująca region i który mógłby stanowić swoisty punkt odniesienia w działalności edukacyjnej skierowanej do młodzieży. Jak stwierdził amerykański literaturoznawca Herbert Grabes, stworzenie takiego kanonu jest istotne dla prowadzenia procesów „wychowywania" grupy i utrzymywania jej pamięci kulturowej ${ }^{23}$. W Sandżaku działania te są inspirowane przez przedstawicieli poszczególnych kręgów politycznych, którzy za pośrednictwem instytucji kulturalnych lub naukowo-akademickich propagują rozwijanie kultury boszniackiej w Sandżaku. Według opinii E. Kazaza, budowa ortodoksyjnego kanonu to nic innego jak ścista, najbliższa wspótpraca panujacej ideologii z instytucją akademicką ${ }^{24}$. Za placówki naukowo-edukacyjne, których przedstawiciele zaangażowani są w promocję języka boszniackiego na gruncie regionalnym, uznaje się,

20 Do niektórych z opisywanych przeze mnie wydarzeń nie podaję źródeł zewnętrznych, ponieważ informacje zdobyłam poprzez osobisty udział (obserwacja uczestnicząca) w obchodach Dnia Sandżaku w 2020 roku.

21 Ćamil Sijarić (1913-1989), pisarz urodzony w czarnogórskiej części Sandżaku. Większość życia spędził w Sarajewie. Jego dzieła tłumaczone były na wiele języków. Po polsku ukazało się tłumaczenie książki Konak, wydanej jako: Ja, eunuch, tłum. D. Cirlić-Straszyńska, Warszawa 1975.

22 Por. Dan Sandžaka 2010, „Mešihat“, https://mesihat.org/2010/11/10/dan-sandaka-2010/ [dostęp: 03.01.2021]; Program za Dan Sandžaka, „Minority news”, https://www.minoritynews.rs/program-zadan-sandzaka/ [dostęp: 03.01.2021]; , Rewda” obilježila Dan Sandžaka, Sana news, https://www.youtube.com/watch?v=ZKAVUDzKXYU [dostęp: 03.01.2021]; 13. Sandžački književni susreti, „Minority news", https://www.minoritynews.rs/13-sandzacki-knjizevni-susreti/ [dostęp: 03.01.2021].

$23 \mathrm{H}$. Grabes, Cultural memory and the literary canon, [w:] Cultural memory studies: an international and interdisciplinary handbook, red. A. Erll, A. Nünning i in., Berlin 2008, s. 311-313.

${ }^{24}$ E. Kazaz, Nacionalni književni kanon - mjesto moći, „Sarajevske sveske” 2005, nr 8/9, s. 123 133. 
obok wspomnianej wcześniej Boszniackiej Rady Narodowej, Boszniacką Akademię Nauki i Sztuki (Bošnjačka Akademija Nauka i Umetnosti, BANU) oraz Boszniacką Wspólnotę Kulturalną (Bošnjačka kulturna zajednica, BKZ). Obie jednostki to instytucje prywatne, pierwsza o profilu edukacyjnym i kulturowym, druga o charakterze naukowym. Trzeba jednak zaznaczyć, że ich utworzenie związane było z istniejącym W regionie polityczno-religijnym podziałem wśród muzułmanów: miały stanowić odpowiednik do istniejącej już organizacji Bośniacka Wspólnota Kultury „Odrodzenie” (Bošnjačka Zajednica Kulture „,Preporod”, BZK) z siedzibą w Sarajewie, działającej również w Sandżaku. Chociaż nazewnictwo tych instytucji sugeruje naukowość, niejednokrotnie ich członkowie posługiwali się w swoich przemowach lub dziełach argumentami sprzecznymi z nauką ${ }^{25}$. Ważną rolę w tej dziedzinie odegrał także prominentny duchowny muzułmański, mufti Muamer Zukolić (1970-2021), który był jednym ze współzałożycieli BKZ (2009) i BANU (2011). W latach 1993-2016 pełnił on ważne funkcje na różnych szczeblach instytucji islamskich w Republice Serbii. W 2007 roku stanął na czele jednej z dwóch muzułmańskich wspólnot wyznaniowych (IZ Srbije). W 2016 roku został wybrany do parlamentu Serbii, a rok później został liderem Partii Sprawiedliwości i Pojednania (Stranka Pravde i Pomirenja, SPP), która wyłoniła się z SDA Sandżaku. W kontekście jego aktywności publicznej przed nazwiskiem często pojawiało się słowo „akademik”, które zwyczajowo jest przypisywane członkom Akademii Nauki i Sztuki, jeszcze zanim założył swoją akademię ${ }^{26}$. Po niespodziewanej śmierci w listopadzie 2021 roku, w życiu politycznym zastąpił go jego syn, Usame Zukorlić.

Zwyczaj wręczania nagród literackich podczas uroczystości Dnia Sandżaku można uznać za etap inicjacji na drodze, jaką dane dzieło musi przebyć, aby zostać włączone do tworzonego kanonu kulturowego. Interesująco o praktyce przyznawania nagród i wyróżnień literackich w Serbii pisze w swojej pracy doktorskiej Biljana Grujičić. Jak wyliczyła ona, obecnie funkcjonuje tam ponad 300 wyróżnień tego typu. Niestety autorka poddała analizie tylko tzw. dyskurs centralny. Przemilczała inicjatywy podejmowane przez środowiska, reprezentujące mniejszości etno-narodowe czy regionalne ${ }^{27}$. Tymczasem należy podkreślić, że w samym Nowym Pazarze działają obecnie cztery różne gremia, przyznające nagrody twórcom literackim. Tylko jed-

25 Patrz: dalsza część artykułu i przypis 42.

26 Muamer Zukorlić był także założycielem i pierwszym rektorem Międzynarodowego Uniwersytetu w Nowym Pazarze (Internacionalni Univerzitet u Novom Pazaru; 2002-2008). Jest to uczelnia prywatna, która powstała dzięki funduszom pozyskanym od władz Republiki Serbii i ponad dwustu darczyńców. Uniwersytet jest oficjalnie uznany, jednak przez wiele lat wśród kilkunastu kierunków studiów w ofercie tylko kilka z nich było akredytowanych. Według M. Zukorlicia, problemy z akredytacją miały podłoże polityczne, jako że instytucja była kojarzona przez władze ze środowiskiem propagującym ideologie boszniacką. W największym ośrodku miejskim Sandżaku działa także uczelnia publiczna, Państwowy Uniwersytet w Nowym Pazarze (Državni Univerzitet u Novom Pazaru).

27 Por. Б. Грујичић, Књижевне награде у Србији као средство културне политике, Београд 2017, https://nardus.mpn.gov.rs/handle/123456789/9210?locale-attribute=en [dostęp: 10.03.2021]. 
no przedsięwzięcie, związane z nagrodą im. Aladina Lukača, jest otwarte na twórców pochodzących spoza Sandżaku. Pozostałe trzy (nagrody im. Ahmeda Vali, im. Amira Dautovicia i Pero Ćamila Sijarića) są adresowane wyłącznie do lokalnych autorów, tworzących w języku boszniackim.

Tylko pozornie wypowiedzi miejscowych liderów podczas Dni Sandżaku nastawione są na poszanowanie dla różnorodności kulturowej regionu. W oficjalnym przekazie eksponowana jest teza, że jest to święto wszystkich mieszkańców Sandżaku, a więc Boszniaków, Serbów, Czarnogórców i Albańczyków ${ }^{28}$. Stałym elementem oficjalnych wypowiedzi jest także podkreślanie nawiązań do czasów II wojny światowej. Stworzona w 1943 roku Ludowa Antyfaszystowska Rada Wyzwolenia Narodowego Sandżaku, jako organ polityczny reprezentowała do roku 1945 wszystkich mieszkańców regionu, zgodnie z partyzanckim hasłem „Braterstwo i jedność”. W zasadzie był to jedyny okres, gdy Sandżak funkcjonował na zasadzie wydzielonego elementu w strukturze komunistycznego ruchu oporu — miał coś na kształt swojego parlamentu i rządu z siedmioma ministerstwami. Przemawiający podczas Dni Sandżaku często podkreślają tradycję wspólnej walki ludności Sandżaku z faszyzmem, niezależnie od narodowości. W 2020 roku burmistrz Nowego Pazaru Nihat Biševac (SDP) powiedział:

Sandżak od zawsze był symbolem jedności i szanowania różnic. Ta data jest ważna dla nas wszystkich, ponieważ zobowiązuje nas do poszanowania idei i dziedzictwa antyfaszyzmu oraz praw człowieka. Od dziesięcioleci jesteśmy przykładem wzajemnego szacunku i współistnienia.

Sandžak je oduvek bio simbol jedinstva i poštovanja različitosti. Ovaj datum važan je za sve nas jer nas obavezuje na poštovanje ideja i tekovina antifašizma i poštovanja ljudskih prava. Decenijama smo primjer međusobnog uvažavanja i suživota ${ }^{29}$.

W podobnym tonie wypowiedział się dwa lata wcześniej założyciel i lider Partii Akcji Demokratycznej Sandżaku Sulejman Ugljanin:

Osiągnięcia naszych przodków, z których wszyscy jesteśmy dumni, mają dziś jeszcze większą wartość, ponieważ stanowią wspólne dziedzictwo wszystkich narodów, które od wieków żyją w harmonii na tym obszarze. W przyszłości Sandżak także postrzegamy jako jednostkę terytorialną złożoną z równych obywateli i zamieszkujących go narodowości.

28 M. Omerović, Dan Sandžaka i Aćif Efendija, https://www.danas.rs/dijalog/licni-stavovi/dan-san dzaka-i-acif-efendija/ [dostęp: 04.01.2020].

29 Jeśli nie zaznaczono inaczej, wszystkie przekłady cytatów są mojego autorstwa (N. Cz.-A.); Zvaničici Grada Novog Pazara čestitatli 20. novembar Dan Sandžaka, „Snews”, https://www.snews.rs/zva nicici-grada-novog-pazara-cestitatli-20-novembar-dan-sandzaka/ [dostęp: 04.01.2020]. 
Tekovine naših predaka, na koje smo svi ponosni, danas imaju još veću vrijednost jer predstavljaju zajedničko naslijedje svih naroda koji vijekovima u harmoniji žive na ovim prostorima. Mi Sandžak i u budućnosti vidimo kao teritorijalnu cjelinu ravnopravnih gradjana i naroda koji u njemu žive ${ }^{30}$.

Coroczne uroczystości Dnia Sandżaku odbywają się jednak w pomieszczeniach wykorzystywanych przez instytucje oraz organizacje propagujące boszniacką narrację narodową w Sandżaku, a więc BNV, Międzynarodowy Uniwersytet w Nowym Pazarze i tamtejsze Centrum Kultury ${ }^{31}$. Podczas celebry, elementy nawiązujące do miejscowych tradycji ludowych mieszają się z treściami i rytuałami o proweniencji religijnej. Pod względem sposobu prezentowania tematyki i charakteru przekazu, uroczystości te są adresowane do lokalnych społeczności muzułmańskich. Przedstawiciele innych grup etniczno-religijnych z Sandżaku nie byli i nie są oficjalnie zapraszani na te imprezy. I tak, w 2010 roku, przy okazji obchodów Dnia Sandżaku, mufti reprezentujący IZ BiH M. Zukorlić zaprosił wszystkich obecnych na specjalne przyjęcie, zorganizowane z okazji islamskiego święta Bajram ${ }^{32}$. W tym przypadku warto powołać się na teoretyczne rozważania polskiego socjologa Radosława Zenderowskiego, który stwierdził, że celem działań uwzględniających treści wyznaniowe w celebracji świąt o charakterze publicznym jest „sakralizacja etnosu”. Polega ona na przypisaniu danej grupie etnicznej, w tym przypadku definiowanej jako szandżacko-boszniacka, wartości religijnych ${ }^{33}$. Zintensyfikowaniu tego przekazu służy używanie odpowiednio dobranej symboliki, uwzględniającej odniesienia religijne, która ma na celu zbliżenie ludzi w oparciu o wspólną, zrytualizowaną tożsamość. W przypadku obchodów Dni Sandżaku ważną rolę odgrywają flagi z symboliką sandżacko-boszniacką, eksponowane w przestrzeni publicznej. Jak napisała Anna Jagiełło-Szostak,

Złote lilie na niebieskim tle przedstawiają autochtoniczność Boszniaków z Sandżaku oraz symbolizują ich europejskie pochodzenie. Białe półksiężyce na zielonym tle wskazują na islamską przynależność opisywanej mniejszości oraz na orientalno-islamską kulturę i tradycję. Z kolei biały pas jest symbolem łączącym europejskie pochodzenie i islamską przynależność ${ }^{34}$.

30 20. novembar - Dan Sandžaka, „SDA”, https://www.sda.rs/vijesti/2361-20-novembar-\%E2\% 80\%93-dan-sandzaka.html [dostęp: 04.01.2020].

31 Podział na dwie rywalizujące ze sobą wspólnoty wyznaniowe i powiązane z nimi partie nie wpływa na moją analizę, ponieważ kreowany dyskurs jest ten sam — to zróżnicowanie ma charakter czysto polityczny, a nie kulturowy.

32 S. Novosel, Počelo obeležavanje Dana Sandžaka, https://www.danas.rs/drustvo/pocelo-obeleza vanje-dana-sandzaka/ [dostęp: 03.01.2021].

33 R. Zenderowski, Etnizacja religii i sakralizacja etnosu: nacjonalizm w Europie Środkowo-Wschodniej, „Athenaeum” 2010, t. 24, s. 38.

34 A. Jagiełło-Szostak, Społeczno-polityczne aspekty tożsamości narodowej Boszniaków z Sandżaku, „Wschodnioznawstwo" 2015, nr 1, s. 317. Obwód tarczy herbowej Sandżaku jest ozdobiony złotym kolorem. Tarcza jest przecięta po skosie białym pasem, w górnej części znajdują się trzy białe półksiężyce na zielonym tle, w dolnej części trzy złote lilijki na granatowym tle. 
Bez wątpienia flaga Sandżaku, wykorzystywana przez przedstawicieli miejscowej społeczności boszniackiej, ma charakter ekskluzywistyczny. Mieszkający na tym terenie prawosławni Serbowie nie utożsamiają się ani z uwzględnionymi tam symbolami islamu, ani ze złotymi liliami, które identyfikują z symboliką narodową i polityczną Boszniaków z BiH. Na szczególną uwagę zasługuje także kwestia sposobu budowania tzw. sfery sacrum przy okazji obchodów Dni Sandżaku. Osoby przemawiające podczas tych uroczystości zazwyczaj są uznawane za liderów w różnych dziedzinach życia lokalnego, utożsamianego z etnosem boszniackim. Są wśród nich politycy, ludzie nauki (historycy, literaturoznawcy, językoznawcy) oraz artyści ${ }^{35}$. W swoich wypowiedziach osoby te niemal wyłącznie odwołują do poczucia wspólnoty boszniackiej, podkreślając jej głębokie zakorzenienie we współczesnych i historycznych realiach regionu. Podczas tych uroczystości nie ma miejsca na eksponowanie konkurencyjnych treści.

Oficjalnie, formuła obchodów Dni Sandżaku, które są uznawane za święto regionalne usankcjonowane przez państwo serbskie, zobowiązuje uczestników do podkreślania aspektu koegzystencji wielonarodowej, w nawiązaniu do tradycji walk $\mathrm{z}$ siłami faszystowskimi podczas II wojny światowej ${ }^{36}$. $Z$ drugiej strony osoby, odpowiedzialne za organizację święta, przy innych okazjach dają się poznać jako rzecznicy stanowisk podważających istnienie ponadetnicznej wspólnoty interesów w regionie. Na przestrzeni lat poszczególni działacze, znani z oficjalnych wystąpień podczas Dni Sandżaku, żądali na przykład rehabilitacji kontrowersyjnego burmistrza Nowego Pazaru z czasów II wojny światowej Acifa Hadžiahmetovicia (znanego jako Aćif Efendija lub Aćif Bljuta), który po wojnie został oskarżony o współpracę z Niemcami i rozstrzelany. Obecnie wielu boszniackich działaczy z Sandżaku uznaje tę postać za bohatera, który działał w imię zapewnienia bezpieczeństwa miejscowym muzułmanom, zagrożonym atakami ze strony partyzantów i czetników. Z inicjatywy BNV w 2012 roku odsłonięto poświęconą mu tablicę pamiątkową, w uroczystości uczestniczył wspomniany Sulejman Ugljanin i czołowi działacze SDA ${ }^{37}$. W kwietniu 2019 roku SDA zaproponowała modyfikację nazewnictwa dwóch ulic w Nowym Pazarze. Forsowano nadanie im imion Aćifa Efendijego oraz prezydenta BiH (19901996) Aliji Izetbegovicia. Działania te doprowadziły do zaognienia sporów na temat współczesnej historii miasta, a także Sandżaku. Zwracano uwagę, że zależnie od okoliczności te same osoby i grupy polityczne prezentowały sprzeczne narracje. Widoczne były próby manipulowania nastrojami społecznymi i dążenia w kierun-

35 Na przykład historyk Harun Crnovršanin, patrz: Skrivena historija Sandžaka, Harun Crnovršanin, https://www.youtube.com/watch?v=_g_uOXw8cAo\&t=7s [dostęp: 04.01.2020].

$36 \mathrm{~W}$ oficjalnych przemówieniach incydentalnie pojawiają się wątki nawiązujące do idei współpracy ponadgranicznej, nawiązujące do doświadczeń Unii Europejskiej. O stworzeniu regionu, nawiązującego do historycznego Sandżaku, opartego na współpracy międzypaństwowej i międzynarodowej mówił m.in. M. Zukorlić.

37 Prije 75 godina na Hadžetu je strijeljan Aćif Efendija, „Snews”, https://www.snews.rs/prije-75godina-na-hadzetu-je-strijeljan-acif-efendija/ [dostęp: 04.01.2020]. 
ku podkreślania odrębnego stanowiska wobec rzeczywiści społeczno-kulturowej ${ }^{38}$. Dodajmy, że działania na rzecz rehabilitacji A. Hadžiahmetovicia korespondowały ze stanowiskiem Islamskiej Wspólnoty Serbii. Na jej stronie internetowej zamieszczono artykuł, w którym aktywność tej kontrowersyjnej postaci ukazano w pozytywnym świetle ${ }^{39}$.

Obserwując ten stan rzeczy, warto jeszcze raz spojrzeć na opisaną wcześniej sytuację w Sandżaku, postrzeganą przez pryzmat relacji pomiędzy tzw. centrami a podwójną peryferią. Rozbieżność w dyskursie, prezentowanym przez miejscowe elity boszniackie, występująca pomiędzy wizją Sandżaku jako regionu stricte boszniackiego a obszarem pokojowego współistnienia różnych narodów, zapewne wynika z konieczności wyodrębnienia przekazów, które są kierowane do dwóch różnych adresatów, z jednej strony władz w Belgradzie, z drugiej do miejscowej ludności muzułmańskiej. Dla przedstawicieli ,peryferii” istotne jest przedstawienie ich dążeń w zgodzie z odgórnie formułowanymi oczekiwaniami, odpowiadającymi oficjalnej polityce państwa wobec mniejszości narodowych. Celem drugiego przekazu, zwróconego w kierunku tzw. swoich, jest cementowanie tożsamości, która bazuje na boszniackim nacjonalizmie i regionalizmie. Działania te można utożsamić ze strategią wykluczenia, które opisuje socjolog Tomasz Rawski w kontekście dążeń do homogenizacji własnej grupy docelowej. Ich celem jest zawężenie kryteriów przynależności do narodu boszniackiego do tych atrybutów, które mogłyby świadczyć o jego całkowitej odrębności od narodu serbskiego ${ }^{40}$.

Ważną częścią Dnia Sandżaku w 2018 roku była projekcja filmu dokumentalnego pt. Sandżak na przestrzeni dziejów (Sandžak u vremenu). Jest to półgodzinna produkcja, w której narrator podaje podstawowe informacje geograficzne i opowiada historię regionu od drugiego tysiąclecia p.n.e. do czasów współczesnych. Warstwę wizualną tworzą liczne mapy, fragmenty ekranizacji fabularnych, kadry przyrody, zdjęcia twierdz i innych budowli, wycinki starych tekstów, gazet oraz kilka współczesnych ujęć. Twórcą filmu jest dr. Jahja Fehratović, stojący na czele Wydziału Filologii prywatnego Międzynarodowego Uniwersytetu w Nowym Pazarze, przewodniczący Boszniackiej Wspólnoty Kulturowej. Jest on uznawany za prominentnego przedstawiciela miejscowej elity intelektualnej, opublikował pokaźną antologię literatury san-

38 M. Nićiforović, Bura u Novom Pazaru: SDA traži ulicu za Aćif-efendiju, Rugovu, Izetbegovića, https:/www.novosti.rs/vesti/naslovna/politika/aktuelno.289.html:791004-SDA-NAPUSTILA-SEDNICU-SKUPSTINE-NOVOG-PAZARA-Ne-odustaju-od-imena-ulica-po-Rugovi-Demaciju-Poluzi-i-Acifefendiji [dostęp: 04.01.2020].

39 BNV: “Aćif efendija je spasio Novi Pazar od četnika“, „Mešihat”, https://mesihat.org/2012/08/17/ bnv-qaif-efendija-je-spasio-novi-pazar-od-etnikaq/ [dostęp: 04.01.2020].

40 T. Rawski, Boszniacki nacjonalizm. Strategie budowania narodu po 1995 roku, Warszawa 2018, s. 7. Korzystam z dostępnej w Internecie dysertacji doktorskiej, której promotorem był prof. Jarosław Kilias, https://depotuw.ceon.pl/bitstream/handle/item/2932/3502-DR-SOC-117642.pdf?sequence=1 [dostęp: 20.12.2020]. W 2019 roku w Warszawie została ona wydana w formie książki pod tym samym tytułem. 
dżacko-boszniackiej. W filmie znalazła się informacja m.in. o tym, że w czasach jugosłowiańskich muzułmańskim kobietom zabraniano zakrywać głowy z powodów religijnych, a gmina wyznaniowa została ogołocona z nieruchomości. W intencji twórców te oraz inne informacje, które pojawiły się w dokumencie, miały świadczyć o ucisku doznawanym przez muzułmanów z Sandżaku ze strony różnych reżimów politycznych, a także dominujących politycznie grup narodowo-wyznaniowych. Nie wspomniano, że rekwizycje ziemi dotyczyły w socjalistycznej Jugosławii wszystkich instytucji o charakterze religijnym, na pierwszy plan wysunięto natomiast cierpienia wyznawców islamu z Sandżaku. Film sprowokował dyskusję na temat sposobów instrumentalizowania przeszłości regionu w przekazach medialnych i artystycznych. Dodatkowe kontrowersje odnosiły się do wypowiedzi przedstawicieli organizatorów, którzy podkreślali, że Boszniacy z Sandżaku jako jedyni byli narodem „autochtonicznym", wywodzącym swoje pochodzenie w prostej linii od Ilirów ${ }^{41}$. Choć z naukowego punktu twierdzenia te brzmią absurdalnie, nadal wybrzmiewają one w wystąpieniach części lokalnych działaczy boszniackich ${ }^{42}$. Zachowania te można uznać za sprzyjające ugruntowaniu się mitu historiograficznego. Informacje, które nie mają uzasadnienia w wiarygodnych źródłach, przedostają się do narracji historycznej, a wielokrotnie powtarzane zakorzeniają się w przestrzeni publicznej ${ }^{43}$. Uwagę zwraca w tym przypadku oparcie dziejów narodu boszniackiego na twierdzeniach o jego autochtonizmie i jednocześnie braku powiązań ze Słowianami-Serbami, a także promowanie idei „sandżackiego narodu" 44 . Nieco zmodyfikowana teza o ilirskim pochodzeniu pojawia się we wspomnianym filmie. Według jego autorów Boszniacy nie są potomkami Ilirów w prostej linii, ale jako jedyni w czasach plemiennych wchłonęli ich kulturę i przejęli dziedzictwo. Inne plemiona natomiast mordowały i dewastowały wszystko wokół siebie. Dodajmy, że przekazy podkreślające ponadhistoryczny związek pomiędzy poszczególnymi współczesnymi narodami bałkańskimi a Ilirami, których uznaje się za ludność rdzenną na Bałkanach, występują także w tradycyjnej serbskiej i albańskiej narracji narodowo-historycznej.

Oczywiście praktyki odnoszące się do kreowania boszniackiej tożsamości w Sandżaku, widoczne podczas corocznych obchodów tego święta, budzą niepokój

41 S. Novosel, Bošnjaci Sandžaka su autohton narod, https://www.danas.rs/drustvo/bosnjaci-sandzaka-su-autohton-narod/ [dostęp: 04.01.2020]; SDA Sandžaka: Bošnjaci su narod, autohton u Sandžaku, „Snews”, https://www.snews.rs/sda-sandzaka-bosnjaci-su-narod-autohton-u-sandzaku/ [dostęp: 04.01.2020].

42 Por wypowiedzi M. Zukorlicia, historyka Haruna Crnovršanina, prof. Suada Kurtćehajicia, prof. Jahji Fehratovicia; Premijerno - Pogledajte dokumentarni film - Sandžak u vremenu, „Sandžakpress”, https://sandzakpress.net/premijerno-pogledajte-dokumentarni-film-sandzak-u-vremenu/ [dostęp: 04.01. 2021].

43 J. Topolski, op. cit., s. 205-206.

44 Lokalni aktorzy życia społecznego posługują się głównie etnonimem Boszniak, dodając często wyróżnik terytorialny np. sandżacki/z Sandżaku, czasami używając określenia Sandžaklija. Nie uważam tego jednak za element wyodrębniający nowy naród, lecz jedynie charakterystykę regionalną, jak np. Šumadinac, Vojvođanin itd. 
wśród serbskiej części ludności. Z kolei władze serbskie prowadzą wobec Sandżaku ostrożną politykę. Starają się nie zaogniać sytuacji w zróżnicowanym kulturowo i religijnie regionie, jednocześnie reagują na każdy najmniejszy nawet sygnał mogący spowodować przeniesienie dyskusji o przyszłości Sandżaku na poziom relacji międzypaństwowych. Stanowisko władz jest oparte na przekonaniu, że sprawa Sandżaku nie stanowi zasadniczego problemu w całokształcie spraw dotyczących serbskiej polityki regionalnej, narodowościowej czy wyznaniowej. Poszczególne wspólnoty narodowe posiadają swoje legalne przedstawicielstwa w Serbii, ich status jest regulowany na podstawie ustawy o ochronie praw i wolności mniejszości narodowych z 2004 roku. Można zaobserwować, że w oficjalnych przekazach media ogólnopaństwowe stosują jednak swoistą „taktykę zapomnienia”, ignorując głosy dochodzące z Sandżaku, domagające się chociażby jego autonomii. Nie oznacza to negowania specyfiki kulturowej, historycznej czy religijnej tego regionu (tak czynią tylko skrajnie nacjonalistyczne środowiska w Serbii) ${ }^{45}$. Chodzi raczej o maksymalne ograniczenie obecności spraw Sandżaku w polityce wewnętrznej państwa, także przy uwzględnieniu kwestii społeczno-gospodarczych. Zdaniem przedstawicieli miejscowych środowisk boszniackich, regres gospodarczy w regionie, w połączeniu z wysoki bezrobociem i dużą emigracją młodych ludzi, to rezultaty zaniedbań w polityce kolejnych rządów serbskich, którym ma zależeć na utrzymaniu peryferyjnego charakteru Sandżaku.

\section{WNIOSKI}

Dni Sandżaku to obecnie jedna ze sztandarowych manifestacji tożsamości boszniackiej na terenie Republiki Serbii. Moje doświadczenie, związane z osobistym odbiorem opisywanego święta i oparte na rozmowach przeprowadzonych z boszniackimi mieszkańcami Sandżaku, wskazuje na relatywnie niewielkie zainteresowanie miejscowej ludności mocno upolitycznionym przekazem, który dominuje podczas corocznych uroczystości. Wpływ na relatywizację odbioru dni Sandżaku mają oczywiście podziały istniejące wśród społeczności muzułmańskiej oraz rywalizacja pomiędzy poszczególnymi aktorami miejscowej sceny społeczno-politycznej. W rezultacie oddziaływanie dni Sandżaku na kolektywną świadomość Boszniaków z regionu jest raczej ograniczane, a wpływa na to również bierność prezentowana przez większość mieszkańców w sferze aktywności publicznej czy obywatelskiej. Obywatele nie mają wiary we własną sprawczość i jednocześnie starają się zachować bezpieczny dystans wobec poszczególnych idei lub haseł. W rezultacie można odnieść wrażenie, że tzw. narracja tożsamościowa, rozwijana przez stosunkowo nieliczne miejscowe elity społeczno-polityczne ma relatywnie słaby wydźwięk w sferze publicznej. Z drugiej strony z niepo-

45 Obradović: Bosanski je varijanta srpskog jezika, Sandžak ne postoji - to je Raška oblast, https://dveri.rs/vesti/konferencije-za-medije/obradovic-bosanski-je-varijanta-srpskog-jezika-sandzak-nepostoji-to-je-raska-olast/ [dostęp: 28.07.2021]. 
kojem należy skonstatować fakt, że upolitycznione przekazy o wydźwięku narodowym, pochodzące od części środowisk politycznych czy naukowych, przeczą chęci zrozumienia innych aktorów dyskursu, a w dalszej perspektywie mogą prowadzić do negowania zasad poszanowania odrębności, istniejących w regionie.

Osoby publiczne, uczestniczące w obchodach Dni Sandżaku, podkreślają w przemowach, że jest to święto wszystkich mieszkańców regionu, z drugiej strony praktyki codziennego przekazu i porządku pozaświątecznego niejednokrotnie zaprzeczają tym zapewnieniom. Właściwie wszystkie imprezy włączone w program tych świąt oraz pozostałe manifestacje i festiwale, są obchodzone w gronie ludzi myślących tak samo, bez udziału przedstawicieli innych grup ludności. Wrażenie to potwierdzają przekazy medialne ${ }^{46}$. W relacjach lokalnej stacji telewizyjnej RTVNP na temat święta dominują elementy kojarzące się z tradycją islamu, pomijane są natomiast odniesienia do wielokulturowej rzeczywistości Sandżaku ${ }^{47}$.

Dzięki cyklicznemu odbywaniu rytuału, jakim jest coroczny Dzień Sandżaku, umożliwiona została reprodukcja boszniackiej tożsamości narodowej w warstwie symbolicznej. Wypowiadane treści, odnoszące się do przeszłości, często mają charakter mitu historiograficznego. Niektóre informacje podawane są jako fakty, choć nie mają oparcia w żadnych wiarygodnych przekazach naukowych. Ta niechęć poddawania własnych konstatacji testowi falsyfikacji ${ }^{48}$, prowadzi do ich "unieruchomiania” w narracji, kierowanej do muzułmańskich społeczności z Sandżaku. Hasła i opinie, zasłyszane od przedstawicieli elit występujących podczas jednego z najważniejszych świąt regionalnych są ponawiane przez kolejnych członków wspólnoty w innych okolicznościach. Podobna tendencja odnosi się do „sublimacji przeszłości” z myślą o historycznym dowartościowaniu etnosu boszniackiego w realiach obecnej Republiki Serbii, a także do procesu etnicyzacji religii, gdzie elementy powiązane z islamem stają się kluczowymi symbolami dla tożsamości narodowej muzułmanów z Sandżaku.

\section{BIBLIOGRAFIA}

Assmann J., Collective Memory and Cultural Identity, „New German Critique” 1995, nr 65.

Durkheim É., Elementarne formy życia religijnego, Warszawa 1990.

Dolińska K., Teoretyczne i metodologiczne aspekty badania sąsiedztwa na pograniczu, [w:] Sąsiedztwa III RP - Czechy. Zagadnienia społeczne, red. M. Dębicki, J. Makaro, Wrocław 2013.

Grabes H., Cultural memory and the literary canon, [w:] Cultural memory studies: an international and interdisciplinary handbook, red. Erll A., Nünning A. i in., Berlin 2008, s. 311-319.

Hobsbawm E., Ranger T., Tradycja wynaleziona, przeł. M. Godyń, F. Godyń, Kraków 2008.

46 Por. Koncertom sevdalinki proslavljen Dan Sandžaka: Obeležen nacionalni praznik Bošnjaka, „Kurir”, https://www.kurir.rs/vesti/srbija/3365289/koncertom-sevdalinki-proslavljen-dan-sandzaka-obele zen-nacionalni-praznik-bosnjaka [dostęp: 03.01.2021].

47 Dan Sandžaka, „RTV Novi Pazar”, https://www.youtube.com/watch?v=uHGia9lVtgY [dostęp: 04.01.2021].

48 J. Topolski, op. cit., s. 206 
Hughson M., Poluperiferija i rod. Pobuna konteksta, Beograd 2015.

Jagiełło-Szostak A., Społeczno-polityczne aspekty tożsamości narodowej Boszniaków z Sandżaku, „Wschodnioznawstwo” 2015, nr 1, s. 305-319.

Jawoszek A, Boszniacy. Literackie narracje tożsamościowe po 1992 roku, Poznań 2014.

Kazaz E., Nacionalni književni kanon - mjesto moći, „Sarajevske sveske” 8/9, Sarajevo 2005, s. 123 133.

Kazaz E., Treći svijet i njegova mudrost isključenosti. Slika imperijalne ideologije i prosvjetiteljske utopije u Andrićevoj Travničkoj hronici, [w:] Slika drugog u balkanskim i srednjoevropskim književnostima, red. M. Maticki, Beograd 2006. [Слика другог у балканским и средњоевропским кљижевностима, red. М. Матицки, Београд 2006].

Kołodziejczak M., Rocznicowe rytualy smoleńskie w perspektywie neodurkheimizmu, „Przegląd Politologiczny" 2015, nr 2, s. 147-159.

Magala S., Double peripherisation, „Review” 1985, t. 9, nr 1, s. 139-151.

Mikucka-Wójtowicz D., Sytuacja mniejszości boszniackiej w Sandżaku - wyzwania i problemy, „Sprawy Narodowościowe" 2013, nr 42, s. 143-167.

Niedźwiecka-Iwańczak N., Granice a pogranicze i transnarodowość, [w:] Transgraniczność w perspektywie socjologicznej. Europa - podzielona wspólnota?, red. M. Zielińska, D. Szaban, B. Trzop, Zielona Góra 2018.

Nora P., Between memory and history. Les lieux de mémoire, „Representation” 1989, nr 26, 1989.

Rawski T., Boszniacki nacjonalizm. Strategie budowania narodu po 1995 roku, Warszawa 2019.

Szpociński A., Miejsca pamięci (lieux de mémoire), „Teksty Drugie” 2008, nr 4.

Szpociński A., Wizualizacja pamięci społecznej, [w:] Pamięć zbiorowa jako czynnik integracji i źródło konfliktów, red. A. Szpociński, Warszawa 2009.

Topolski J., Jak się pisze i rozumie historię. Tajemnice narracji historycznej, Warszawa 1996.

Zalewski K. M., Naród, religia, rasa. Muzułmańskie ideologie i tuchy narodowe pogranicza w Poludniowo-Wschodniej Europie. Przykład Sandżaka nowopazarskiego w XX wieku, Warszawa 2010, s. 81.

Zenderowski R., Etnizacja religii i sakralizacja etnosu: nacjonalizm w Europie Środkowo-Wschodniej, „Athenaeum” 2010, t. 24, s. 38.

\section{Źródla internetowe}

13. Sandžački književni susreti, „Minority news”, https://www.minoritynews.rs/13-sandzacki-knjizevnisusreti/ [dostęp: 03.01.2021].

20. novembar - Dan Sandžaka, „SDA”, https://www.sda.rs/vijesti/2361-20-novembar-\%E2\%80\%93dan-sandzaka.html [dostęp: 04.01.2020].

BNV: “Aćif efendija je spasio Novi Pazar od četnika”, „Mešihat”, https://mesihat.org/2012/08/17/bnvqaif-efendija-je-spasio-novi-pazar-od-etnikaq/ [dostęp: 04.01.2020].

Dan Sandžaka, „RTV Novi Pazar”, https://www.youtube.com/watch?v=uHGia9lVtgY [dostęp: 04.01.2021].

Dan Sandžaka 2010, „Mešihat”, https://mesihat.org/2010/11/10/dan-sandaka-2010/ [dostęp: 03.01.2021].

Dan Sandžaka - dan opredijeljenja za jedinstvenu i autonomnu regiju, Matica Bošnjačka, http://www. maticabosnjacka.org/uncategorized/dan-sandzaka-dan-opredijeljenja-za-jedinstvenu-i-autonomnuregiju/ [dostęp: 04.01.2020].

Grujičić B., Književne nagrade u Srbiji kao sredstvao kulturne politike, Beograd 2017, [Грујичић Б., Кьижевне награде у Србији као средство културне политике, Београд 2017.] https://nardus. mpn.gov.rs/handle/123456789/9210?locale-attribute=en [dostęp: 10.03.2021].

Javni čas ,Sandžak kroz historiju”, Bošnjačko nacionalno vijeće, https://www.youtube.com/ watch? $\mathrm{v}=$ LjeqRVIDUHc [dostęp: 04.01.2021].

Milošević S., Ulica Milana Nedića u Aranđelovcu, „N1 info” 2017, http://rs.n1info.com/Vesti/a346534/ Ulica-Milana-Nedica-u-Arandjelovcu.html, [dostęp: 03.01.2021].

Nićiforović M., Bura u Novom Pazaru: SDA traži ulicu za Aćif-efendiju, Rugovu, Izetbegovića, https:// www.novosti.rs/vesti/naslovna/politika/aktuelno.289.html:791004-SDA-NAPUSTILA-SEDNICU- 
SKUPSTINE-NOVOG-PAZARA-Ne-odustaju-od-imena-ulica-po-Rugovi-Demaciju-Poluzi-i-Acifefendiji [dostęp: 04.01.2020].

Novosel S., Počelo obeležavanje Dana Sandžaka, https://www.danas.rs/drustvo/pocelo-obelezavanjedana-sandzaka/ [dostęp: 03.01.2021].

Novosel S., Bošnjaci Sandžaka su autohton narod, https://www.danas.rs/drustvo/bosnjaci-sandzaka-suautohton-narod/ [dostęp: 04.01.2020]; SDA Sandžaka: Bošnjaci su narod, autohton u Sandžaku, „Snews”, https://www.snews.rs/sda-sandzaka-bosnjaci-su-narod-autohton-u-sandzaku/ [dostęp: 04.01.2020].

Obradović: Bosanski je varijanta srpskog jezika, Sandžak ne postoji - to je Raška oblast, https://dveri.rs/ vesti/konferencije-za-medije/obradovic-bosanski-je-varijanta-srpskog-jezika-sandzak-ne-postoji-toje-raska-olast/ [dostęp: 28.07.2021].

Omerović M., Dan Sandžaka i Aćif Efendija, https://www.danas.rs/dijalog/licni-stavovi/dan-sandzaka-iacif-efendija/ [dostęp: 04.01.2020].

Premijerno - Pogledajte dokumentarni film - Sandžak u vremenu, „Sandžakpress”, https://sandzakpress.net/premijerno-pogledajte-dokumentarni-film-sandzak-u-vremenu/ [dostęp: 04.01.2020].

Prije 75 godina na Hadžetu je strijeljan Aćif Efendija, ,Snews”, https://www.snews.rs/prije-75-godinana-hadzetu-je-strijeljan-acif-efendija/ [dostęp: 04.01.2020].

Program za Dan Sandžaka, „Minority news”, https://www.minoritynews.rs/program-za-dan-sandzaka/ [dostęp: 03.01.2021].

Republički zavod za statistiku, http://popis2011.stat.rs/ [dostęp: 04.01.2021].

„Rewda” obilježila Dan Sandžaka, „Sana news”, https://www.youtube.com/watch?v=ZKAVUDzKXYU [dostęp: 03.01.2021].

Sandžak (tag), „Danas”, https://www.danas.rs/tag/sandzak/ [dostęp: 03.01.2021].

Skrivena historija Sandžaka, Harun Crnovršanin, https://www.youtube.com/watch?v=_g_uOXw8cAo\& $\mathrm{t}=7 \mathrm{~s}$ [dostęp: 04.01.2020].

Zvaničici Grada Novog Pazara čestitatli 20. novembar Dan Sandžaka, "Snews", https://www.snews.rs/ zvanicici-grada-novog-pazara-cestitatli-20-novembar-dan-sandzaka/ [dostęp: 04.01.2021]. 